\title{
Benefits and Practical Aspects of Involving Construction Professionals in In- ternational Service-Learning Projects
}

\section{Dr. John E. Greenleaf P.E., Quinnipiac University}

John Greenleaf received his Ph.D. from Lehigh University in 2007 and is a licensed professional engineer. In 2013 he joined Quinnipiac University in Hamden Connecticut to lead the development of a new Civil Engineering program within the newly established engineering school. His professional background includes work in the areas of environmental engineering, construction, service learning projects and undergraduate engineering education. His involvement in service learning projects for more than a decade has included work with Engineers Without Borders, Water for People, and the Tagore-SenGupta Foundation.

\section{Mr. Emils Stires Schnore, Independent construction professional}

Raised by artists. Graduated with a journalism degree from Kutztown University in 1995. In 1996, employed by design/build firm specializing in period respectful restoration/additions with projects focused on artisan quality craftsmanship in all trades. Interested in service learning projects.

\section{Dr. Patrick M. Strenk P.E., Golder Associates, Inc.}

Patrick M. Strenk, Ph.D., P.E. is a former Visiting Assistant Professor in the Civil and Environmental Engineering Department at Lafayette College in Easton, Pennsylvania. Dr. Strenk earned B.S. degrees in civil engineering and geology from Lehigh University in Bethlehem, Pennsylvania, and M.S. and Ph.D. degrees from Drexel University in Philadelphia Pennsylvania specializing in geotechnical earthquake engineering. He is currently a Senior Project Geotechnical Engineer with Golder Associates, Inc. in Reno, Nevada working in the mining industry. 


\title{
Benefits and Practical Aspects of Involving Construction Professionals in International Service-Learning Projects
}

\begin{abstract}
:
International service-learning projects have long been a venue in which engineering educators and practicing engineers can work with and mentor students in their respective disciplines. The benefits of these professional collaborations to service-learning projects and their intended learning objectives have been well documented in the open literature and offer a variety of perspectives including those of students, educators, professionals, community partners and affiliated non-governmental organizations. Despite this added value of collaboration, significantly less consideration has been given to other individuals relevant to the engineering profession; most notably, construction professionals (or contractors). Often, when construction professionals are included in international projects they tend to be procured in-situ from the local/indigenous population and employed only during the construction phase of the project. While often both productive and helpful, these individuals are often lacking in mentorship characteristics and not representative of our domestic construction professionals in both practice and professionalism. Many possibilities exist regarding how the educational experience and the project outcome can be positively influenced by the inclusion of domestic construction professionals in all phases of the project, not just construction. This paper examines some of these potential collaborations and suggests activities that may strengthen this student-mentor partnership. A collaboration including educators, practicing engineers, and contractors models good professional practice and helps bridge the gaps between theory, practice, and practicality in engineering design. Given these potential benefits, this work also examines some of the practical aspects related to locating, engaging and retaining these individuals as partners in successful service-learning projects.
\end{abstract}

\section{Background:}

In recent years, service-learning opportunities and participation have increased substantially in higher education ${ }^{1,2,3}$ and in particular in the realm of engineering education ${ }^{4,5,6}$. Non-profit 301(c) groups such as Engineers Without Borders (EWB) and Water for People (WFP) are common partners with engineering programs and their presence has grown dramatically over the past decade. These service-learning projects have been found to be unique environments where active learning can take place and an engaged campus can be cultivated ${ }^{7,8,9,10}$. Principal stakeholders in these types of projects may include: (i) students; (ii) educators; (iii) practicing engineers; (iv) construction professionals; (v) beneficiaries (individuals, groups or communities) and (vi) non-profit organizations.

The benefits provided to each of the various stakeholders is an element critical to the overall success and sustainability of the project. The primary benefits of a project, such as capacity building, improved sanitation and access to clean drinking water are often accompanied by other important "secondary" benefits. Learning is one example of a key "secondary" benefit with students being the (primary) intended recipient. Table 1 lists specific learning outcomes 
commonly associated with these service-learning activities. It should be noted that the benefit of learning is not exclusive to students and it is often shared by many if not all of the stakeholders $^{11,12}$.

Table 1: Common Learning Outcomes With Respect to Student Service-Learning Projects

\begin{tabular}{|l|l|}
\hline \multicolumn{1}{|c|}{ Outcome } & \multicolumn{1}{c|}{ Aspects of the Outcome } \\
\hline $\begin{array}{l}\text { Increased academic } \\
\text { improvement }\end{array}$ & Learning, critical thinking, writing \\
\hline Moral development & Values, activism, racial/cultural understanding \\
\hline Self-efficacy & $\begin{array}{l}\text { Turning a design into a completed project, } \\
\text { successful team involvement }\end{array}$ \\
\hline Leadership & Taking charge of a project, interpersonal skills \\
\hline $\begin{array}{l}\text { Commitment to service- } \\
\text { learning }\end{array}$ & $\begin{array}{l}\text { Understanding its value, post-graduation } \\
\text { participation }\end{array}$ \\
\hline
\end{tabular}

Kendall describes the mechanism by which learning is synthesized within a project using the concept of reciprocity ${ }^{13}$. In service-learning, reciprocity is a state where all stakeholders are engaged in learning. "All parties in service-learning are learners and help determine what is to be learned. Both the server and those served teach and both learn." 13 Through this reciprocity, learning is one of the most significant benefits to all stakeholders that is derived from the project. This benefit is also the foundation of the partnership between stakeholders. Grobe sees the question of benefits as a means of differentiating between a "true partnership" and other relationships ${ }^{14}$. True partnerships develop when "mutual benefits" exist between all engaged parties; other relationships where these benefits are absent cannot be a true partnership. Without mutual benefit (such as between all stakeholders in a service-learning project), a true partnership cannot exist. The importance of developing and nurturing these partnerships is critical to the service-learning project. Subsequently, the improvement of these partnerships is key to improving the service-learning activity at large. ${ }^{15,16}$ This work examines how involving construction professionals (CPs) contribute to learning in an international service-learning environment and suggests possibilities for both developing and strengthening the partnership with these individuals in order to improve the experience as a whole.

\section{Common Mentors in International Service-Learning Projects:}

Project mentors are an important stakeholder in service-learning projects. These individuals represent a variety of different professions and often have a significant impact on learning 
objectives. Of these various professions, CPs typically represent only a small percentage of mentors in international service-learning projects. To obtain a broad perspective on the composition of project mentors, post-implementation reports for fourteen (14) international projects involving student chapters of Engineers Without Borders (EWB) were examined. The mentor composition of these projects is depicted in Figure 1. Most notably, academics and professional engineers are the predominate participants. The benefits of having both professors and practicing engineers collaborating to mentor the students are clear: together they help bridge the gap between academic learning and professional practice. Other disciplines involved were generally diverse and included construction professionals, graduate student assistants, scientists, and business professionals to name a few.

Besides academic faculty and professional engineers, CPs also played a critical role in the projects examined. Interestingly, while CPs comprised only $4.4 \%$ of the overall mentor population, they participated in the vast majority of student projects. Present as both laborers and contractors, they are often responsible for bringing the project design to completion and critical to supplementing the student workforce. Considering this dichotomy, it became clear that two distinct groups of construction professionals were engaged in international service-learning projects: 1) Domestic Construction Professionals (DCP), or individuals brought from the U.S. and serving in some mentorship capacity and 2) Indigenous Construction Professionals (ICP), or individuals procured from the local population.

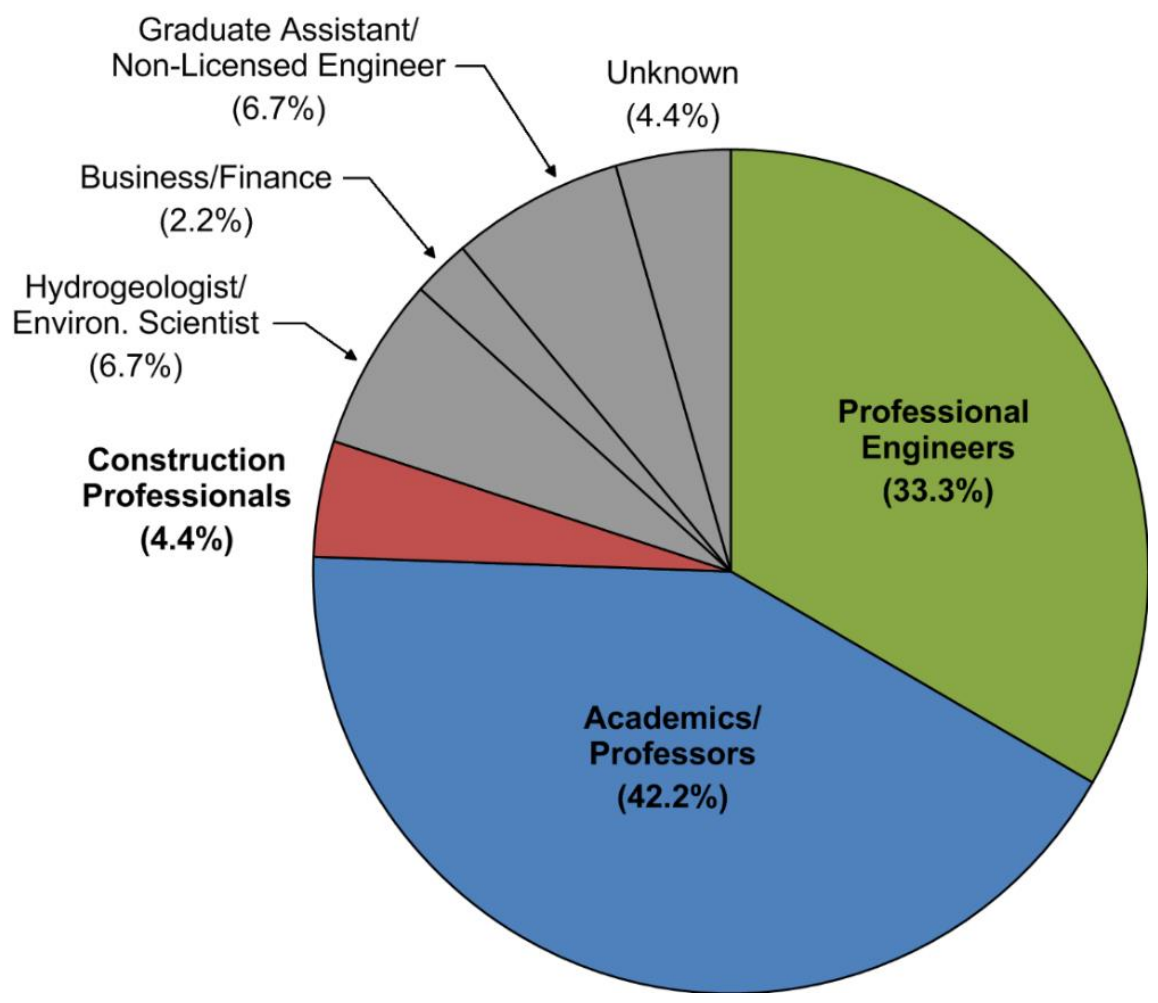

Figure 1. Mentor composition of 14 International Engineers Without Borders student chapter projects. 


\section{Inclusion of Domestic Construction Professionals Adds Value:}

In general, construction professionals (both DCP and ICP) should be considered a valuable resource to both the student and project for organizations involved in international servicelearning projects. Additionally, the construction professional is rewarded with a unique experience working with a variety of individuals while being given the opportunity to share ideas and experiences with other professionals and students. Focusing on the student-construction professional relationship, one can consider again Kendall's concept of reciprocity and map out the flow of benefits to and from the various groups. Figure 2 depicts this reciprocity between the student and the two types of construction professionals.

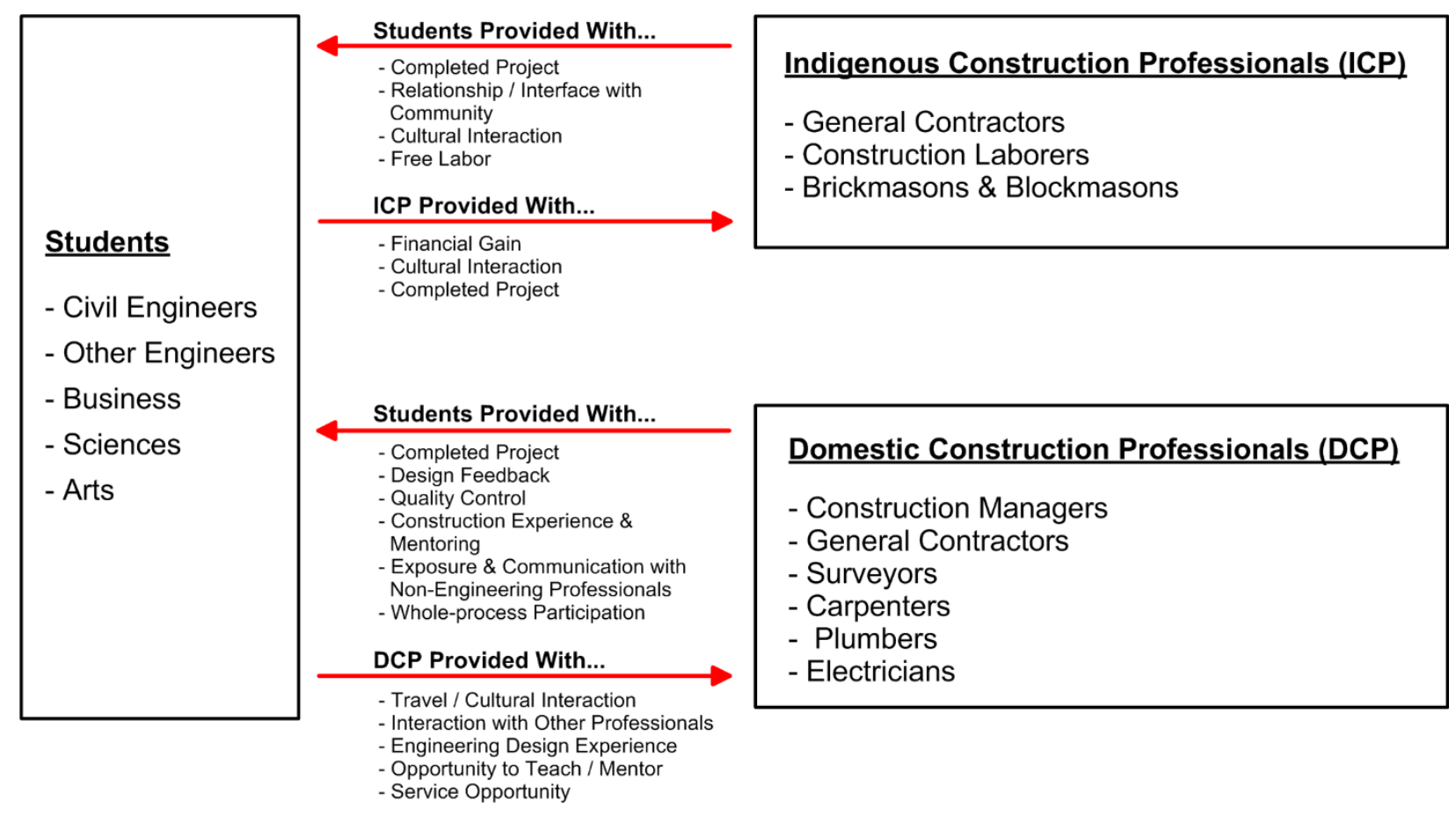

Figure 2. The reciprocity of benefits shared between students, indigenous construction professionals and domestic construction professionals during a typical international servicelearning project.

While some of the benefits are similar between the two types of contractors (e.g., both provide the students with a completed project), many are quite different. For the ICPs, most benefits exchanged with the students are either cultural in nature or directly related to the completion of the project (e.g., students get a completed design and the ICPs village gets a new water system). At times there may be the additional benefit of financial compensation, in this instance, the 
student group may compensate an indigenous contractor to help in the construction of a system. Additionally, some of this value presented by ICPs may be unique and cannot be duplicated by DCPs. For instance, ICPs may have unique experience in understanding the indigenous population, site and surrounding geography, accessibility and transport of local materials, and familiarity with local labor. The value offered by ICPs is especially crucial during the process of implementation and construction in the field.

Alternatively, when considering the student exchange with DCPs, it can be seen that the benefits are both broader, and for the students, more closely related to the learning objectives of servicelearning projects. Receiving feedback on design practicality, learning construction methodology, communication of construction issues and obtaining field construction experience are largely related to outcomes such as leadership and self-efficacy as listed in Table 1. On a broader scale, DCPs help encourage the students toward project completion, add continuity by making sure the students are prepared to address the tasks and field issues presented them and ensure the students safely construct the project. When considering the reciprocity generated between students and DCPs, it is clear this this relationship is not only beneficial, but also something uniquely provided by the DCP alone. Domestic construction professionals can serve as a key ingredient, and this strong DCP-student relationship is the foundation for both a strong student-mentor partnership and a successful project.

\section{Modeling Good Professional Practices:}

Since the service-learning project often serves as a model for the civil engineering and construction industries, it is also important that the project realistically reflect these career eventualities. However what is unclear for service-learning projects is what this representative set of mentors should look like, especially with respect to the role of the DCP. Insight into this can be found by understanding the DCPs typical involvement in a service learning project and whether they are involved to an appropriate extent or under-represented throughout the duration of the project. While it is recognized that a student chapter would have difficulty incorporating a host of DCPs in an overseas project, it would seem like the limited participation of DCPs (2 out of 14 projects, Figure 1) indicates a possible under-representation in the projects examined considering that their indigenous counterparts were used at least to some extent in the vast majority of the projects. Qualitatively speaking, one would want to include DCPs in the project to the extent that they: (i) add value to the learning outcomes of the project; and (ii) appropriately represent engineer-contractor interaction in professional practice, which the project (at least in part) is trying to model.

By examining U.S. Bureau of Labor Statistics data for 2012, a more quantitative approach was taken to examine the proportion of occupations involved in typical civil engineering professional practice. Figure 3a depicts some of the major industries that employ civil engineers. The three predominate industries are: (i) architectural and engineering services; (ii)non-residential building construction; and (iii) state government at $51.5 \%, 13.1 \%$ and $11.2 \%$, respectively. By then considering the occupational make- up of these different principal industries (Figures 3b, 3c, 3d), one can also gain insight to those with whom a civil engineer will interact with on a professional basis. 


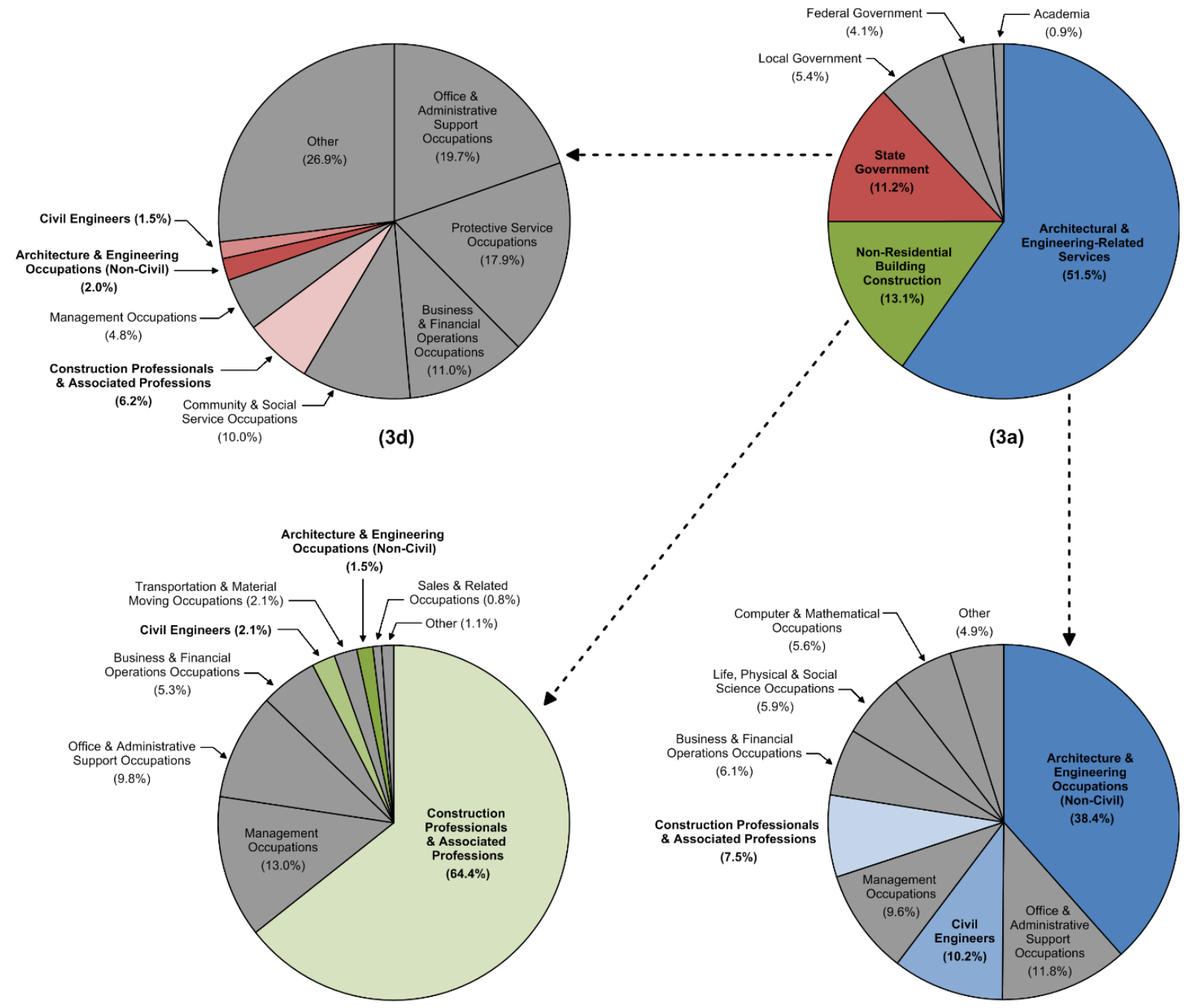

(3c)

(3b)

Figure 3a. Employment of U.S. civil engineers by industry group; 3b Occupational composition of the architectural and engineering services industry; 3c Occupational composition of the nonresidential building construction industry; 3d Occupational composition of the state government industry;

If we consider the architectural and engineering services industry, it can be seen that engineers comprise the majority of occupations, though a substantial amount of these engineers are in disciplines outside of civil engineering (38.4\%) (Figure 3b). While civil engineers occupy a significant role in this industry $(10.2 \%)$, it can be seen that construction professionals are present as well and represent $7.5 \%$ of the industry. This trend is reversed as we consider the nonresidential construction and state government sectors (Figures 3c, 3d). For civil engineers 
entering the construction industry, the proportion of fellow engineers (both civil and otherwise) will shrink and the proportion of construction professionals will grow to a significant extent $(64.4 \%)$. For civil engineers following this career path, a working relationship with construction professionals is often a daily reality. Likewise, in the state government sector, the proportion of civil engineers is dwarfed by an array of non-engineering professions. However, construction professionals again represent a significant proportion of these industry occupations $(6.3 \%)$.

From this data, it can be seen that the civil engineering profession in general is exceedingly diverse, and as such, these percentages may not necessarily represent the actual day-to-day interactions of any given engineer. However, considering these industry trends, some broad conclusions can be drawn regarding the career of a civil engineer and the appropriate level of DCP participation in a typical construction project. First, the typical engineer will be exposed to, and have to interact with, a variety of occupations during their career. Among these, practicing engineers and construction professionals account for a significant proportion in a variety of industry sectors. Second, when comparing a service-learning project (e.g., water systems, structures, etc.) to these different industry groups, it becomes clear the non-residential building construction industry sector most closely resembles the typical service-learning project environment in terms of both work environment and stakeholder composition. Based on this similarity, it is clear that strong DCP participation would closely emulate the industry environment and is key factor in enhancing the benefits to all stakeholders in a service-learning project.

\section{Inclusion of DCPs in a Service-Learning Project:}

DCPs should be included in all phases of a service-learning project. Just as the inclusion of practicing engineers has great benefit during the design phase, the inclusion of DCPs during the planning and construction phases can have wide-ranging benefits. Broadly speaking, there is the potential for DCPs and practicing engineers to participate in all phases of the project, with this approach being reflective of a typical design-build construction process ${ }^{17}$. Table 2 illustrates a suggested scheme for the participation and intensity of involvement for various stakeholders throughout the life of a typical international service-learning project.

Service-learning projects can be fairly involved and require extensive logistical considerations, especially when they occur outside of the United States. Obtaining a DCP early in the project can help significantly. When fielding prospective projects and during initial investigations, a DCP may have insight into what types of supplies and materials as well as tools and labor will be involved. These factors are critical in understanding if the project will be sustainable in the proposed locale. During the design and planning stages, a DCP can help save the project team time and effort by making suggestions concerning the practicality of early ideas. Designs generated by students, because of their lack of field experience, may not initially consider realworld implementation. This early pre-implementation preparation can help students feel confident in their designs and give them a better idea of how they will come together. In addition, DCPs with their hands-on capabilities, practical knowledge and construction lexicon can be the primary means of building positive interactions and working relationships with local ICPs as well as enhancing the confidence of community members in the success of the project. 
Table 2. Participation and intensity of involvement for the various stakeholders during the life of a service-learning project.

\begin{tabular}{llll}
\hline \multicolumn{1}{c}{ Project Phase } & $\begin{array}{c}\text { Participate in } \\
\text { Travel Visits }\end{array}$ & $\begin{array}{c}\text { Participate in } \\
\text { Domestic Activities }\end{array}$ & $\begin{array}{c}\text { Indigenous } \\
\text { Participants }\end{array}$ \\
\hline Initial investigation & S, F & S, F, PE, DCP, OP & B, NGO \\
\hline Design & S, F, PE, OP & S, F, PE, DCP, OP & B, ICP, NGO \\
\hline $\begin{array}{l}\text { Pre-implementation } \\
\text { planning }\end{array}$ & S, F, PE, OP, & S, F, PE, DCP OP & B, ICP, NGO \\
\hline Construction & S, PE, DCP, F & S, F, PE, DCP & B, ICP, NGO \\
\hline Closeout & S, PE, DCP & S, F, PE, DCP & B, NGO, ICP \\
\hline
\end{tabular}

Key: "S"= student, "F" = Faculty, "PE" = Practicing Engineer, "DCP" = Domestic Construction Professional, "ICP" = Indigenous Construction Professional. "OP" = Other Professional (scientist, geologist, business), "B" = Beneficiaries, "NGO" = Non-governmental organization collaborator. Boldface Type $=$ intense level of involvement likely.

This relationship between DCP mentor and student is fostered by the give-and-take between them during the design and implementation phases of a project and can be further enriched by DCP workshops given prior to travel. This workshop and relationship building process has been utilized by the authors in preparation for several international project implementation trips. Table 3 lists potential workshop topics, many of which focus on basic building techniques. These workshops can help give team members a picture of the processes they may encounter before arriving at a project work site. In addition, a DCP can help introduce team members to a builder's lexicon and basic methodology. Also, early involvement of a DCP can help build a solid working relationship between these future engineers and a type of professional they may encounter upon graduation and employment.

Continuing this relationship throughout the design and implementation process can also help in a variety of additional factors that increase the likelihood of success for the project. These factors include: value engineering (improve function and/or cost), injecting construction knowledge into the design process (practicality/feasibility), quality assurance, cost estimation, construction techniques, and scheduling. Lastly, a substantial advantage for adding a DCP to a project team is that after the project's completion the DCP remains available to them. The project and all of its phases can be reviewed and discussed. Successes, failures, and "lessons learned" from a project can be reviewed with the DCP participating in the preparation of the post-implementation report and any "as-built" drawings. This information can be then used for planning and refining methodologies or implementation procedures prior to the start of future projects. Collaboration (and associated learning) that includes faculty, practicing engineers, and construction professionals throughout the project life models good professional practice, builds "true" partnerships and helps bridge the gaps between theory, practice, and practicality in engineering design for the participating students. 
Table 3. Workshop topics and associated activities where domestic construction professionals can participate as mentors to service-learning projects.

\begin{tabular}{|c|c|}
\hline $\begin{array}{l}\text { Workshop Topic } \\
\text { (suited to a specific project) }\end{array}$ & Description of Activity \\
\hline Basic site layout & $\begin{array}{l}\text { - } \quad \text { Site preparation for excavation } \\
\text { - } \quad \text { Using laser level to establish benchmark. } \\
\text { - } \quad \text { Layout basics for locating structure/pad }\end{array}$ \\
\hline Basic framing & $\begin{array}{l}\text { - } \quad \text { Lumber, fasteners, and construction techniques } \\
\text { - } \text { Plates, stud spacing, and bracing } \\
\text { - } \quad \text { Assembly of concrete form work }\end{array}$ \\
\hline Plumbing basics & $\begin{array}{l}\text { - Basics of plumbing tools, materials, and fittings } \\
-\quad \text { Solvent welding plastic pipe } \\
-\quad \text { Galvanized iron pipe threading } \\
-\quad \text { Determining lengths and fitting pipe }\end{array}$ \\
\hline Concrete mixing & $\begin{array}{l}\text { - } \text { Associated tools and techniques } \\
-\quad \text { Recipes to attain required concrete strength } \\
\text { - } \quad \text { Finishing basics }\end{array}$ \\
\hline Concrete placement & $\begin{array}{l}- \text { Subgrade preparation } \\
-\quad \text { Basics of pouring concrete for walls and slabs } \\
-\quad \text { Re-bar basics (placing, tying) } \\
-\quad \text { Curing, jointing and weather issues }\end{array}$ \\
\hline Masonry basics & $\begin{array}{ll}- & \text { Mortar mixing } \\
- & \text { Block/brick laying and pointing } \\
\end{array}$ \\
\hline General organization & $\begin{array}{l}- \text { Generating tools and materials lists } \\
-\quad \text { Cost estimating } \\
-\quad \text { Scheduling basics } \\
-\quad \text { Organization of labor. } \\
-\quad \text { Establishing protocol for field decisions }\end{array}$ \\
\hline Safety & $\begin{array}{ll}- & \text { Protective gear } \\
- & \text { Site safety and OSHA guidelines } \\
\end{array}$ \\
\hline
\end{tabular}

\section{Identifying, Engaging, and Retaining Construction Professionals:}

Most service-learning projects will prove to be a very different experience from a DCP's regular occupation. Construction professionals may welcome this unique experience and the opportunity to interact with students, academics, engineering professionals and also the indigenous population. To facilitate this experience, the question of how to build this relationship with a DCP is critical, and identifying the type of construction professional needed is the first step. Skill in the various trades, construction management and surveying would be the talents most beneficial to a project, while laborers could be retained from the indigenous population. Additionally, while it is important to consider the skills needed to complete a particular project, 
the existing skill set possessed by both the students and the mentors must also be considered. Further consideration must be given to the skills that the students wish to acquire and the benefits the students and mentors have to offer the DCP in return.

Beyond construction-related skills, there is a significant chance that a DCP may have experience working within a college/university environment, in a service-learning project, or both. These individuals will most easily identify with the other groups involved in the project and have a sense of the educational expectations and outcomes desired from the project. Figure 4 depicts U.S. Bureau of Labor Statistics data for 2012 as mean income versus mean educational attainment level (as defined by the International Standard Classification of Education, 1997) for some of the occupations associated with non-residential construction (refer to Figure 3c). On average, most DCPs that would be involved with a service-learning project (managers, surveyors, carpenters, plumbers, etc.) have some level of college education. For example, according to U.S. Bureau of Labor Statistics data for 2012, 12.4\% of carpenters have an Associate's degree or higher with $32 \%$ having some exposure to college coursework. In addition to education, DCPs may already be involved with similar service projects that may include Habitat for Humanity, The Peace Corps, religious/missionary groups, or other volunteer work. These experienced partners may often be unaware of other service-oriented opportunities associated with engineering programs at colleges and universities.

In terms of finding professionals, it is possible that professional engineers and engineering educators involved in a service-learning organization might be able to refer one directly from their work experience. Other indirect referrals may come from alumni who work in the construction industry, parents/relatives of students or sub-contractors that work for the college/university. In the latter case, the facilities planning department at a college/university may provide useful contact information or the facilities members themselves may be interested in participating. Placing an advertisement seeking applicants for a service-learning project in construction magazines/journals is another option. These advertisements can be tailored to the skills and qualifications needed for a given project. For instance, if a general contractor is needed, a solicitation could be placed in Fine Homebuilding or the Journal of Light Construction. If a mechanical contractor would benefit the project, an advertisement in Plumbers and Mechanics magazine might be more appropriate. With countless magazines and journals specializing in every trade, the search can be simplified by advertising in a publication focusing on the type of DCP needed. Also there are numerous construction trade organizations and occupational unions that can provide useful contact information. Again, the key is to contact the organization whose members provide the greatest level of synergy with the project and learning goals.

Once a DCP mentor is identified, the process of engagement and relationship-building can begin. It is important to recognize that for the relationship and project to be successful, one cannot expect a DCP to be recruited, travel, and complete a project at a moment's notice. Relationship building is key and time is needed to determine if the DCP is appropriate for the project, specifically in terms of skills, interest, personality, and mentorship qualities. By involving the DCP in "low stakes" activities such as workshops, design presentations, and other preimplementation activities the relationship can be allowed to develop while also benefiting the project. Service-learning organizations should also expect to fairly compensate DCPs for their 
efforts during a project. Figure 4 also shows how income can vary across the disciplines associated with a project. The mean annual income of DCPs varies significantly based on occupation, however, the most important factor to consider is the effect of hourly versus salary wage. For many DCPs, an hourly salary makes participation difficult especially when it comes to travel. Two weeks of missed wages due to meetings, workshops and site visits is often a significant inhibitor when it comes to participation. Matching the DCP's normal salary should be expected. As with other mentors, any travel related expenses and inoculations should also be covered.

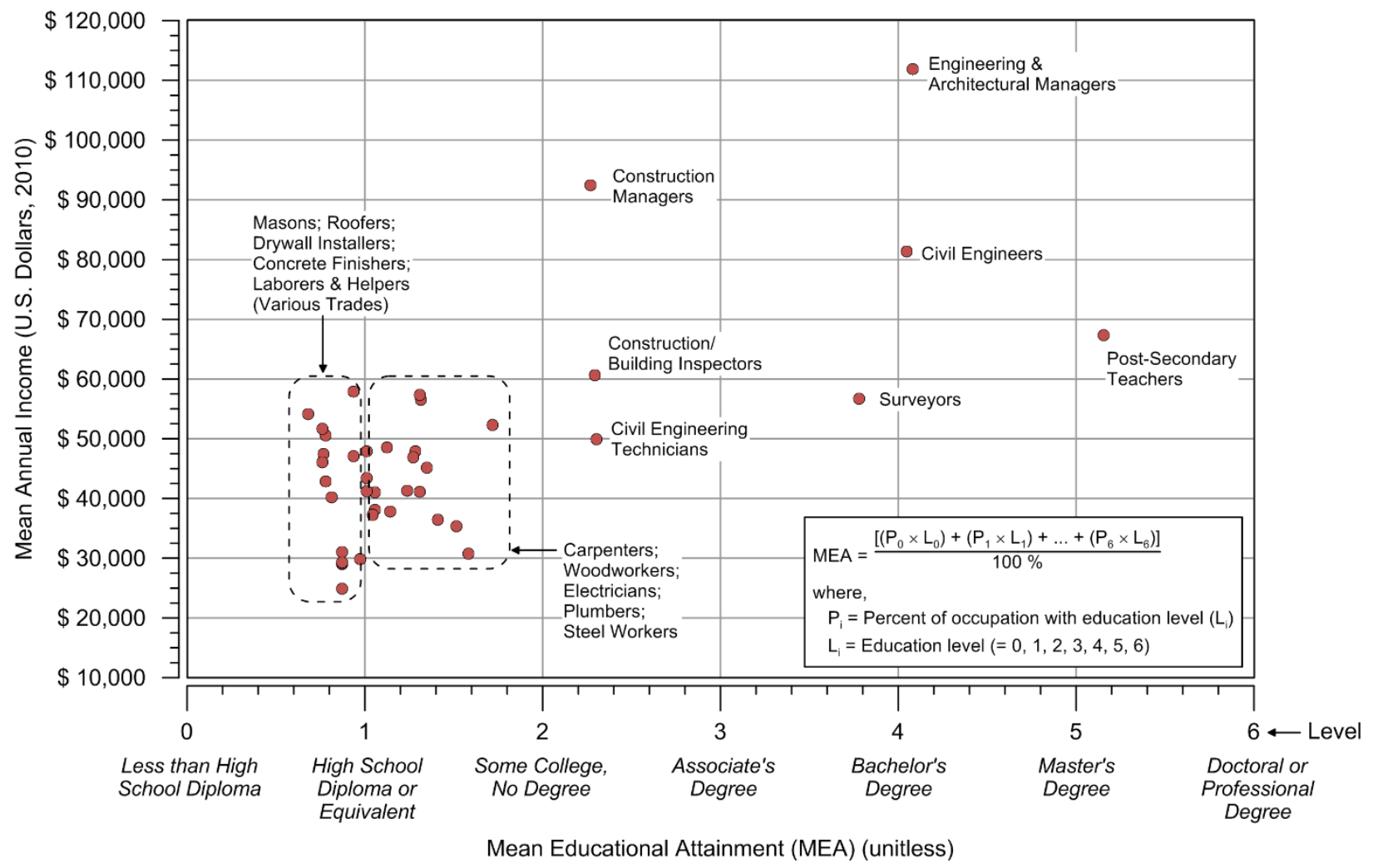

Figure 4. Mean income versus mean educational attainment for occupations associated with non-residential construction.

Initial engagement of a partner DCP is undoubtedly the most difficult step. While these difficulties may be logistical in nature, at other times they may also be prejudicial. There are many instances where engineers and contractors maintain an uneasy or unequal working relationship. Service-leaning projects offer a unique opportunity to set a good example for the students by listening to the input of CPs who have been traditionally looked down upon (blue versus white collar). Overcoming this stereotype can be an important step in a young engineer's career development and one that is nearly impossible to convey in the classroom. Being able to foster these relationships between construction professionals and the next generation of civil 
engineers is critical to both overcoming these relationship barriers and completing a successful service-learning project.

\section{Conclusions:}

Domestic construction professionals represent an important yet underutilized group of mentors for international service-learning projects. The inclusion of these individuals has the potential to create stronger partnerships and thus better outcomes for all project stakeholders. The value of this partnership can be realized throughout the life of the project in the form of attaining learning objectives, more comprehensive project planning, broader professional development and successful construction practices. From a professional standpoint, this partnership when combined with educators and practicing engineers models good professional practice representative of typical domestic construction activities. While many avenues exist regarding how to engage these individuals, it is important to retain individuals that complement the goals and objectives of the project both in terms of construction and education. Once engaged, this relationship can be further cultivated through workshops, meetings and other low-stakes activities prior to an international trip. Ultimately, the long-term success of this partnership depends on relationship building and the development of shared goals and expectations, mutual respect, learning, and sense of project ownership for all participants.

\footnotetext{
${ }^{1}$ Welch, M. Billig, S.H. (2004). New Perspectives in Service-learning: Research to Advance the Field. Information Age Publishing, Charlotte, NC.

${ }^{2}$ Gonsalves, R.K., (2008) Service-learning from the Perspective of Faculty in Higher Education: A Qualitiative Study., University of Connecticut, Ann Arbor, MI: ProQuest LLC.

${ }^{3}$ Stanton, T.K., Giles, D.E. (1999). Service-Learning, A Movement's Pioneers Reflect on Its Origins, Practice, and Future. Jossey-Bass, San Francisco, CA.

${ }^{4}$ Coyle, E. J., Jamieson, L. H., Oakes, W. C. (2006). “Integrating Engineering Education and Community Service: Themes for the Future of Engineering Education”, Journal of Engineering Education, 95(1), 7-11.

5 Selingo, J. (2006). “May I Help You?” J. ASEE Prism, 15(9), 40-45.

${ }^{6}$ Rodriguez-Falcon, E., Yoxall, A. (2010). "Service-learning Experiences: A Way Forward in Teaching Engineering Students?" Engineering Education, 5(2), 59-68.
} 
${ }^{7}$ Jacoby, B. (1996). Service-Learning in Higher Educations Concepts and Practices. Jossey-Bass, San Francisco, CA.

${ }^{8}$ Speck, B.W., Hoppe, S.L. (2004). Service-Learning History, Theory, and Issues, Praeger Publishers, Westport, CT.

${ }^{9}$ Eyler, J. S., Giles, D. E., Jr., \& Braxton, J. (1997). “The Impact of Service-Learning on College Students”, Michigan Journal of Community Service-learning, 4, 5-15.

${ }^{10}$ Astin, A. W., \& Sax, L. J. (1998). "How Undergraduates are Affected by Service Participation”, Journal of College Student Development, 39(3), 251-263.

${ }^{11}$ Johnson, P.D., Johnson, P.W., Shaney, N. (2008). "Developing Contemporary Engineering Skills Through Service-learning in Peru", Journal of Community Engagement and Scholarship, 1 (1), 81-84.

${ }^{12}$ Lynch, D.R., Russell, J.S. (2009). "Experiential Learning in Engineering Practice”, J. Prof. Issues Eng. Educ. Pract. 135(1), 31-39.

${ }^{13}$ Kendall, T. (1990). Combining Service and Learning: A Resource Book for Community Public Service Volume 1. National Society for Internships and Experiential Education, Raleigh, NC.

${ }^{14}$ Grobe, T., Curnan, S., Melchior, A. (1990) Synthesis of Existing Knowledge and Practice in the Field of Educational Partnerships. Brandeis University Center For Human Resources, Heller Graduate School, Waltham, MA.

15 Jacoby, B. (2003) Building Partnerships for Service-Learning, Jossey-Bass, San Francisco, CA.

${ }^{16}$ Bailis, L.N., (2000) Taking Service-learning to the Next Level: Emerging Lessons from the National Community Development Program, National Society for Experimental Education, Springfield, VA.

${ }^{17}$ Barrie, D.S., Paulson, B.C. (1992). Professional Construction Management, $3^{\text {rd }}$ Edition, McGraw-Hill, New York. 